\title{
Bad medicine
}

\section{An untested herbal product in South Africa is being touted as an effective AIDS treatment-with the full support of a local scientist. Natasha Bolognesi investigates.}

Secomet's AIDS medicine looks nothing like any other drug. For 200 Rands (approximately $\$ 30$ ), you can buy a plastic bottle filled with 500 milliliters of a dark liquid that has the color and consistency of Coca-Cola.

Unlike those pesky pills other companies manufacture, the product made by this South African company goes down easy. All someone has to do is take 15 milliliters of the brown liquid, dubbed V/anti-Vac or Secomet $\mathrm{V}$, mix it with one liter of water and drink it all day.

In its marketing material, the Stellenboschbased company says individuals who take Secomet V "generally experience a lowering of viral load, which allows their CD4 count to stabilize and then to start improving." The company has dubbed the product 'Ithemba Lesizwe', or 'The Hope of the Nation' in the South African language Xhosa.

"We are saying to the 6 million HIV-positive South Africans who don't qualify for ARVs [antiretroviral drugs], 'take this product to stabilize your condition so that you never have to qualify for ARVs,"' says Stephen Leivers, the company's founder and major shareholder.

All of which sounds great. But here, of course, is the catch: Secomet V has never been tested in clinical trials, nor do its makers know how it works.

"There is the evidence that this stuff kills the virus in the lab, what more do you want?" asks Leivers. "There's no time for bullshit. I'm so jaundiced about bloody universities and doctors."

Secomet began peddling its product four years ago, and today boasts more than 1,500 consumers. In South Africa, it's not unheard of for companies such as this to tout 'miracle' therapies. But it's certainly unusual for scientists from well-regarded institutions to support, and even promote, unproven remedies.

Secomet $\mathrm{V}$ has found a champion in Girish Kotwal, a scientist at the prestigious University of Cape Town. Kotwal is chief of medical virology at the university's Institute of Infectious Diseases and Molecular Medicine. Ironically, Kotwal's own laboratory tests-and those by others at the University of Pisa-have shown that the product can be toxic and can trigger mutations.

"Professor Kotwal is dealing with Secomet in his personal capacity and I have told him, in no uncertain terms, that this is unacceptable behavior," says the institute's director Greg Hussey.

Until recently, neither the institute nor the university had taken any official measures. After Nature Medicine began its investigation, however, the university convened an urgent meeting to investigate Kotwal's association with Secomet.

\section{Trial and error}

Secomet V is an extract from the red clover, Trifollium pratense. Individuals are meant to take Secomet $\mathrm{V}$ along with the traditional ARVs, but eventually, according to Leivers, individuals whose T-cell counts rise in response to treatment should be able to stop taking ARVs and continue on Secomet $\mathrm{V}$ alone. The product is marketed to general practitioners and distributed through health shops and African traditional healers or 'sangomas'.

The standard approach to selling a medicine, or to make claims of its efficacy, would be to first run safety trials and then test the product's effectiveness in large, randomized clinical trials, approved by South Africa's Medicines Control Council (MCC) and research ethics committees.

"Yes, medical products have to go through a rigorous scientific review before they are bought, but in the meantime what do you do?" asks Kotwal. "Countries like

...patients generally experience a lowering of viral load, which allows their CD4 count to stabilize and then to start improving.

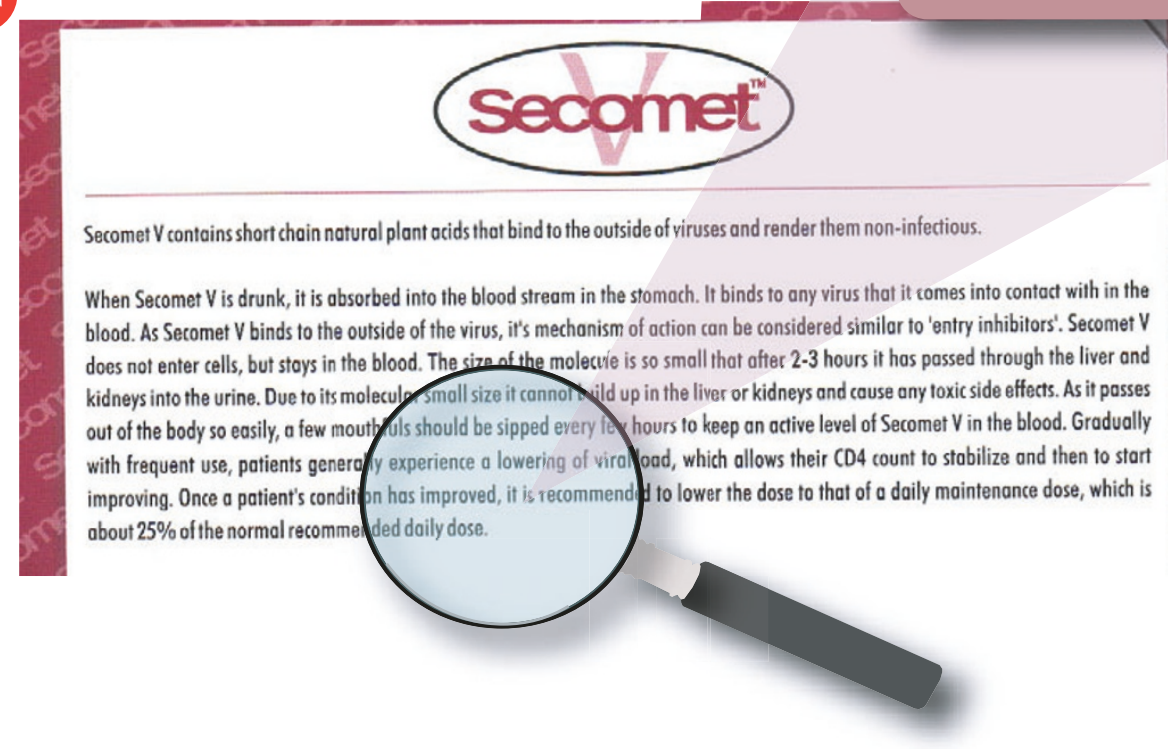

Questionable cure: A brochure for Secomet V says the compound can lower viral loads, but that has never been proven in clinical trials.

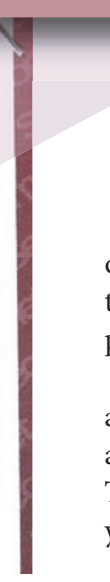

South Africa,

China and

India are vast;

$\mathrm{m}$ a i n s tre a m medicine cannot service the entire region, so they have to rely on

traditional healers to do that. One has to take a kind of liberal view, but things don't run smoothly, people sometimes die through toxicity encountered in natural products."

Kotwal says Secomet V has antiviral activity against HIV, the coronavirus that causes severe acute respiratory syndrome and poxviruses. The mechanism of this action, he says, is "as yet unknown."

As proof of the product's effectiveness, Kotwal proudly refers to his publication in the Annals of the New York Academy of Sciences. According to that report, based primarily on in vitro research and data from four individuals, Secomet is a broadspectrum inhibitor of viral entry (Ann. NY Acad. Sci. 1056, 293-302; 2005). 
In the study, the individuals' CD4 levels dropped steadily over a year, reaching numbers in the low two digits. Kotwal says the numbers eventually increased again at a time that was outside the scope of the article and so he did not show those data.

"It is shocking that the four patients used in the study, with CD4 counts as low as 12 and 16, had access to viral load testing, which is a costly performance, and not to antiretroviral drugs and counseling," says Helmuth Reuter, professor of infectious diseases and director of Stellenbosch University's Ukwanda Centre for Rural Health. "It is actually murderous."

\section{Unknown effects}

In April and May 2005, two individuals at the AIDS Hospice in Stellenbosch died after sudden, inexplicable liver failure. Neither were on ARVs, but both had taken Secomet V, says Lisa Hellstrom, a clinician at the hospital, adding that she is concerned that Secomet V may have damaged their livers.

In May 2006, Hellstrom says, another of her patients who is taking ARVs and Secomet $V$ was found to have abnormal liver enzymes.

There is no information on whether, and how, Secomet V might interact with ARVs, but based on anecdotal evidence, Leivers says there is "no conflict between the medicines."

One of the four individuals in Kotwal's study, referred to as $\mathrm{OH} 2$, also died last year. "It is her own fault because she packed her bags and moved back to the Transkei and stopped taking Secomet," says Leiver.

Kotwal argues that because Secomet V has been on the market, there is plenty of anecdotal evidence to support its safety and efficacy. Although the product should ideally be tested in clinical trials, he says, it can be distributed in the meantime because it is registered with the MCC as an herbal or complementary medicine.

It is not.

Although the product has an internal tracking number at the MCC, agency officials say that it cannot be marketed as an herbal remedy, nor can the company claim that it decreases viral loads. "This claim cannot be made without clinical

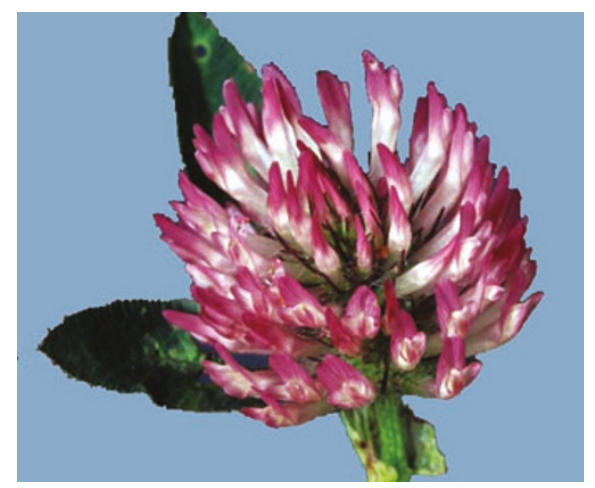

trials," says MCC researcher Dixon Lentsoane.

In vitro tests on African green monkey kidney cells show that the plant extract is toxic when not purified by ultrafiltration. The raw extract also "possesses notable toxicity towards bacterial cells even at lower doses," and can trigger mutations, Kotwal and his colleagues found (Ann. NYAcad. Sci. 1056, 303-310; 2005). Based on their results, the researchers recommended that the safety of the plant extract be thoroughly assessed before its clinical use. "Ultimately the goal is to attain $100 \%$ safety, which
has not happened
yet" Kotwal says yet," Kotwal says.

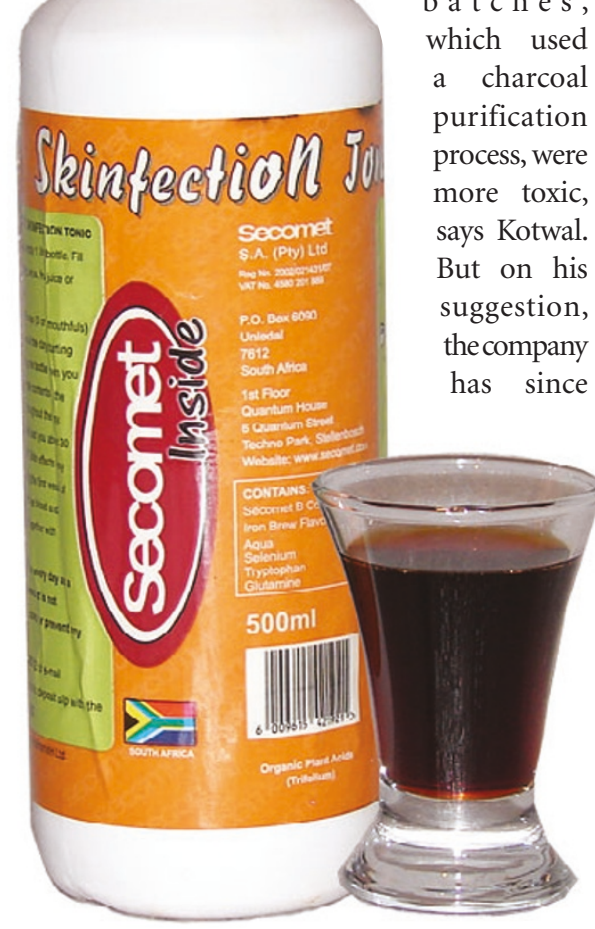

Mysterious medicine: Secomet $\mathrm{V}$ is made from the red clover, Trifollium pratense (lower left), and is sold in 500-milliliter bottles.

begun using a filter, which he says should make the product safer. Pressed for specifics, he says, "we have not actually tested the most recent batches that have been manufactured... one can predict that it is presumably safer than it was because they now use the kilodalton cutoff filter."

\section{Uninformed consent}

Despite the many questions about the product, Kotwal remains convinced of its usefulness. Even after the university began its investigation, he told Nature Medicine, "Secomet as a company has been bullish and boneheaded at times (possibly because of the hurdles that are placed in their path to introducing their products) even in their dealings with us, but that does not mean that they do not have a potentially life-saving treatment for HIV patients who have no access to FDA-approved treatment and have their days numbered."

Secomet is pushing ahead meanwhile. Leivers, in collaboration with Derek Arbuckle from the Dream Centre in Pinetown, is conducting an observational study in 30 individuals with AIDS. Many of them also have tuberculosis and are taking Secomet V as a 'nutritional supplement'.

Neither Arbuckle, nor the study participants, are aware of the potential toxicity. "We have told the [participants] that as far as we are aware there are no toxicity issues," says Arbuckle. The trial participants have signed informed consent forms, drawn up by Arbuckle, to this effect.

Arbuckle says that study does not need MCC approval because it is not a clinical trial. But Mark Blockman, chair of the Research Ethics Committee at the University of Cape Town, says any such study would need the approval of both the MCC and the institutional ethics committee.

Noluntu Qodi, a spokesperson from the MCC Clinical Trials Division, says the company has never approached the agency for permission to conduct trials. "There is no MCC registration for or application by the company Secomet to conduct trials," Qodi says, adding that the MCC will respond to the Secomet trials "in due course."

Meanwhile, the university is continuing its investigation into the matter. Officials there may also need to clarify some financial issues.

For instance, although Leivers was a coauthor on the Annals report, the paper says the "work was not supported by funding from Secomet pvt. Ltd. and is an independent study that was in no way influenced by Secomet." Leivers and Kotwal both declined comment on this apparent conflict of interest.

The University of Cape Town and Secomet also have a sales royalty agreement, ostensibly for the lab work university researchers have contributed to Secomet.

That raises ethical questions because the university is essentially profiting from a product that has not been rigorously tested, says Keymanthri Moodley, a bioethics expert at the University of Stellenbosch.

The university is expected to make a public statement on the matter, but officials decline to reveal when that might be. "The university is addressing the issue," says Hussey. "Kotwal is at fault and needs to apologize for a lack of insight."

Natasha Bolognesi is a freelance writer based in Cape Town.

For more news and analysis go to news@nature.com www.nature.com/news 